\title{
PENGOMPOSAN SEKAM PADI MENGGUNAKAN SLURRY DARI FERMENTASI LIMBAH CAIR PABRIK KELAPA SAWIT
}

\author{
Irvan*, Bambang Trisakti, Cut Novaliani Hasbi, Elwina Widiarti \\ Departemen Teknik Kimia, Fakultas Teknik, Universitas Sumatera Utara, \\ Jl. Almamater Kampus USU, Medan 20155, Indonesia \\ *Email : i_v_a_n_mz@yahoo.com
}

\begin{abstract}
Abstrak
Sekam padi merupakan bahan buangan yang biasanya hanya dibakar. Namun praktek ini menyebabkan timbulnya persoalan pencemaran udara. Salah satu upaya untuk membantu mengatasi permasalahan limbah pertanian adalah melakukan upaya daur ulang dengan penekanan pada proses pengomposan. Berbagai upaya dapat dilakukan untuk mempercepat proses pengomposan. Diantaranya adalah dengan menggunakan cairan (slurry) dari sisa fermentasi limbah cair pabrik kelapa sawit. Perlakuan yang dilakukan adalah penambahan slurry di awal pengomposan sebanyak 1, 2, dan 3 liter dan penambahan slurry selama proses pengomposan dengan menambahkan 0,5; 1 ; dan 1,5 liter slurry setiap 3 hari sekali dimana pada masing-masing perlakuan ditambahkan $1 \mathrm{~kg}$ kompos halus. Dari hasil penelitian memperlihatkan karakter kompos hampir memenuhi kualitas kompos berdasarkan SNI 19-70302004. Kondisi terbaik terdapat pada perlakuan dengan penambahan slurry sebanyak 1,5 liter setiap 3 hari sekali, dimana suhu yang diperoleh yaitu $32,8{ }^{\circ} \mathrm{C}$, kadar air $35,1 \%$, ratio $\mathrm{C} / \mathrm{N} 7,58$ dan pH 9,59. Hal ini menunjukkan bahwa slurry dari fermentor biogas pada pengomposan sekam padi dapat mempercepat kematangan kompos sehingga kompos lebih mudah terurai atau terdekomposisi.
\end{abstract}

Kata kunci : sekam padi, slurry, kompos, limbah cair pabrik kelapa sawit, fermentasi

\begin{abstract}
Rice husk is material waste that is usually just burned. However, this practice is causing air pollution problems. One effort to help overcome the problem of agricultural waste is recycling technique with an emphasis on the process of composting. Many efforts can be made to speed the composting process. The treatment was performed by the addition of slurry at the beginning of composting process with the addition of as much as 1, 2, and 3 liters and the addition of slurry during composting process by adding 0,5; 1; and 1,5 liters of slurry every 3 days once. At each treatment was added $1 \mathrm{~kg}$ of fine compost. The condition which almost meets quality compost by SNI 19-7030-2004 and most precocious and decomposes is the compost with the addition of as much as 1, 5 liters every 3 days where the temperature is $32,8{ }^{\circ} \mathrm{C}$ obtained, the water level is $35,1,99 \%$, the ratio of $\mathrm{C} / \mathrm{N}$ is 7.58 and $\mathrm{pH}$ is 9,59. This thing indicates that the slurry from biogas fermentor can accelerate the maturity of compost making so that it is more easily broken down or decomposed.
\end{abstract}

Keywords : rice husk, slurry, compost, palm oil mill effluent, fermentation

\section{Pendahuluan}

Sekam padi merupakan lapisan keras yang meliputi kariopsis yang terdiri dari dua belahan yang disebut lemma dan palea yang saling bertautan. Pada proses penggilingan beras sekam akan terpisah dari butir beras dan menjadi bahan sisa atau limbah penggilingan. Dari proses penggilingan padi biasanya diperoleh sekam sekitar 20-30\% dari bobot gabah dengan komposisi sekam sekitar 20-30\%, dedak antara 8- $12 \%$ dan beras giling antara $50-63,5 \%$ dari bobot awal gabah [2]. Sekam padi terdiri atas $50 \%$ selulosa, 25-30\% lignin, 15-20\% silika, dan kadar air 9,02\% [7].

Sekam padi merupakan bahan yang relatif kering. Dalam proses pengomposan, kelembaban merupakan faktor yang penting dalam menetukan proses dekomposisi bahan organik. Untuk itu, dilakukan penambahan slurry dengan berbagai volume pada pengomposan sekam padi untuk melihat karakteristik kompos.

Penelitian mengenai sekam padi dan slurry telah banyak dilakukan, diantaranya adalah :

1. Penelitian mengenai pengomposan sekam padi menggunakan organic decomposer berupa cacing tanah dan EM4. Diperoleh, bahwa kompos yang menggunakan organic decomposer berupa cacing tanah memiliki kandungan unsur makro yang lebih baik dibandingkan kompos yang menggunakan EM4 [5]. 
2. Penelitian mengenai slurry dimana dengan penambahan slurry berpengaruh terhadap pertumbuhan tanaman. Dari hasil penelitian diperoleh bahwa pertumbuhan kompos sangat dipengaruhi oleh nilai $\mathrm{C}, \mathrm{N}, \mathrm{P}$ dan $\mathrm{K}$ yang terkandung di dalam pupuk cair slurry [1].

Permasalahan pokok yang akan dijawab dalam penelitian ini adalah mampukah slurry dari fermentasi limbah cair pabrik kelapa sawit dapat mempercepat kematangan kompos dari sekam padi.

\section{Teori}

Slurry merupakan limbah dari proses fermentasi secara anerobik [11]. Slurry yang digunakan berasal dari fermentasi limbah cair pabrik kelapa sawit. Limbah cair pabrik kelapa sawit mengandung bahan organik yang relatif tinggi dan tidak bersifat toksik karena tidak menggunakan bahan kimia dalam proses ekstraksi minyak. Limbah cair pabrik kelapa sawit umumnya bersuhu tinggi, berwarna kecoklatan, mengandung padatan terlarut dan tersuspensi berupa koloid dan residu minyak dengan kandungan biological oxygen demand (BOD) yang tinggi.

Slurry mengalami penurunan COD sebesar 90\% dari kondisi bahan awal dan perbandingan BOD/COD Slurry sebesar 0,37. Nilai ini lebih kecil dari perbandingan BOD/COD limbah cair sebesar 0,5 [11]. Slurry juga mengandung lebih sedikit bakteri pathogen sehingga aman untuk digunakan sebagai pupuk [13]. Tabel 1 memperlihatkan komposisi di dalam slurry.

\section{Tabel 1. Komposisi di dalam Slurry [11]}

\begin{tabular}{|c|l|c|}
\hline No. & Komposisi & Kadar $(\%)$ \\
\hline 1. & Bahan kering & $8-10$ \\
\hline 2. & Kandungan air & $90-92$ \\
\hline 3. & Protein kasar & 14,82 \\
\hline 5. & Serat kasar & 21,78 \\
\hline 6. & Eter ekstrak & 1,2 \\
\hline 7. & Abu total & 23,84 \\
\hline 8. & Nutrisi utama : & $1,5-2,5$ \\
& $\mathrm{~N}_{2}$ & $1,0-1,5$ \\
& $\mathrm{P}_{2} 0_{5}$ & $0,8-1,2$ \\
\hline 9. & $\mathrm{~K}_{2} 0$ & $8,6-21,6$ \\
& asam humat $(\mathrm{P}$ & \\
\hline
\end{tabular}

Slurry mengandung banyak unsur nitrogen yang diperlukan oleh mikroorganisme untuk sintesis protein dalam proses pengomposan.

Pengomposan adalah proses dimana bahan organik mengalami penguraian secara biologis, khususnya oleh mikroba-mikroba yang memanfaatkan bahan organik sebagai sumber energi [8]. Menurut Wahyono pengomposan didefinisikan sebagai proses dekomposisi materi organik secara biologis menjadi material seperti humus dalam kondisi aerobik yang terkendali. Membuat kompos adalah mengatur dan mengontrol proses alami tersebut agar kompos dapat terbentuk lebih cepat. Proses ini meliputi membuat campuran bahan yang seimbang, pemberian air yang cukup, pengaturan aerasi, dan penambahan aktivator pengomposan [12].

Faktor-faktor yang mempengaruhi proses pengomposan antara lain:

1. Rasio $\mathrm{C} / \mathrm{N}$

Rasio C/N yang efektif untuk proses pengomposan berkisar antara 30:1 hingga 40:1. Mikroba memecah senyawa $\mathrm{C}$ sebagai sumber energi dan menggunakan $\mathrm{N}$ untuk sintesis protein. Umumnya, masalah utama pengomposan adalah pada rasio $\mathrm{C} / \mathrm{N}$ yang tinggi, terutama jika bahan utamanya adalah bahan yang mengandung kadar kayu tinggi (sisa gergajian kayu, ranting, ampas tebu, dsb). Untuk menurunkan rasio $\mathrm{C} / \mathrm{N}$ diperlukan perlakuan khusus, misalnya menambahkan mikroorganisme selulotik atau dengan menambahkan kotoran hewan karena kotoran hewan mengandung banyak senyawa nitrogen [10].

\section{Kelembaban (Moisture Content)}

Kelembaban memegang peranan yang sangat penting dalam proses metabolisme mikroba dan secara tidak langsung berpengaruh pada suplai oksigen. Mikroorganisme dapat memanfaatkan bahan organik apabila bahan organik tersebut larut di dalam air. Kelembaban 40-60 \% adalah kisaran optimum untuk metabolisme mikroba.

\section{Aerasi}

Pengomposan yang cepat dapat terjadi dalam kondisi yang cukup oksigen (aerob). Aerasi secara alami akan terjadi pada saat terjadi peningkatan suhu yang menyebabkan udara hangat keluar dan udara yang lebih dingin masuk ke dalam tumpukan kompos. Aerasi ditentukan oleh porositas dan kandungan air bahan (kelembaban). Apabila aerasi terhambat, maka akan terjadi proses anaerob yang akan menghasilkan bau yang tidak sedap. Aerasi dapat ditingkatkan dengan melakukan pembalikan atau mengalirkan udara di dalam tumpukan kompos.

4. Temperatur

Panas dihasilkan dari aktivitas mikroba. Ada hubungan langsung antara peningkatan suhu dengan konsumsi oksigen. Semakin tinggi temperatur akan semakin banyak konsumsi oksigen dan akan semakin cepat pula proses 
dekomposisi. Peningkatan suhu dapat terjadi dengan cepat pada tumpukan kompos.

5. $\mathrm{pH}$

Proses pengomposan dapat terjadi pada kisaran $\mathrm{pH}$ yang lebar. $\mathrm{pH}$ yang optimum untuk proses pengomposan berkisar antara 6,5 sampai 7,5. pH kotoran ternak umumnya berkisar antara 6,8 hingga 7,4. Proses pengomposan sendiri akan menyebabkan perubahan pada bahan organik dan $\mathrm{pH}$ bahan itu sendiri. Sebagai contoh, proses pelepasan asam, secara temporer atau lokal, akan menyebabkan penurunan $\mathrm{pH}$ (pengasaman), sedangkan produksi amonia dari senyawasenyawa yang mengandung nitrogen akan meningkatkan $\mathrm{pH}$ pada fase-fase awal pengomposan. $\mathrm{pH}$ kompos yang sudah matang biasanya mendekati netral [4].

\section{Metodologi Penelitian}

Penelitian mengenai pengaruh penambahan slurry dengan berbagai volume pada kompos sekam padi terhadap karakteristik kompos dilakukan dengan pengukuran suhu dan berbagai analisa seperti kadar air, ratio $\mathrm{C} / \mathrm{N}$ dan $\mathrm{pH}$.

Dalam penelitian ini dilakukan berbagai perlakuan dengan variasi penambahan slurry, seperti diperlihatkan pada Tabel 2 .

\section{Tabel 2. Perlakuan Penelitian}

\begin{tabular}{|c|c|c|}
\hline Perlakuan & $\begin{array}{c}\text { Volume } \\
\text { slurry (liter) }\end{array}$ & $\begin{array}{c}\text { Waktu } \\
\text { penambahan slurry }\end{array}$ \\
\hline 1 & 1 & $\begin{array}{c}\text { Di awal } \\
\text { pengomposan }\end{array}$ \\
\hline 2 & 2 & $\begin{array}{c}\text { Di awal } \\
\text { pengomposan }\end{array}$ \\
\hline 3 & 3 & $\begin{array}{c}\text { Di awal } \\
\text { pengomposan }\end{array}$ \\
\hline 4 & 0,5 & Setiap 3 hari sekali \\
\hline 5 & 1 & Setiap 3 hari sekali \\
\hline 6 & 1,5 & Setiap 3 hari sekali \\
\hline
\end{tabular}

Pada masing-masing perlakuan ditambahkan 1 $\mathrm{kg}$ kompos dan dilakukan pembalikan 2 kali sehari.

Kemudian pengukuran temperatur dilakukan 2 kali sehari sebelum pengadukan. Analisa kadar air dilakukan setiap 5 hari sekali dan setelah \pm 2 bulan dilakukan analisa $\mathrm{C} / \mathrm{N}$ serta $\mathrm{pH}$. Penentuan kadar air dapat dilihat pada persamaan 1.

Kadar air $=\frac{A-B}{A} \times 100 \%$

dimana:

$\mathrm{A}=$ Berat awal sampel (gr)

$\mathrm{B}=$ Berat sampel kering $(\mathrm{gr})$
Penentuan $\mathrm{C}_{\text {organik }}(\%)$ dapat dilihat pada persamaan 2 .

$\mathrm{C}_{\text {Org }}=5\left\lceil 1-\frac{\mathrm{T}}{\mathrm{S}}\right\rceil \times 0,003 \times \frac{1}{0,77} \times \frac{100}{\mathrm{BCT}} \ldots$

dimana :

$\mathrm{T}=$ Volume titrasi larutan $\mathrm{Fe}\left(\mathrm{NH}_{4}\right)_{2}\left(\mathrm{SO}_{4}\right)_{2}(\mathrm{ml})$

$\mathrm{S} \quad=$ Volume titrasi larutan blanko $(\mathrm{ml})$

$\mathrm{BCT}=$ Berat contoh tanah $(\mathrm{gr})$

Penetapan Nitrogen total dapat dilihat pada persamaan 3 .

$\mathrm{N}(\%)=\frac{\mathrm{ml} \mathrm{HCl} \times \mathrm{N} \mathrm{HCl} \times 14 \times 100}{\text { Berat Sampel } \times 1000}$

\section{Hasil dan Pembahasan}

Gambar 1 memperlihatkan pengaruh penambahan slurry pada berbagai volume di awal pengomposan terhadap suhu komposter. Temperatur maksimal yang dapat dicapai kompos yaitu pada perlakuan 1 adalah $30,3{ }^{\circ} \mathrm{C}$, untuk perlakuan 2 adalah $30,1{ }^{\circ} \mathrm{C}$ dan untuk perlakuan 3 adalah $32,1{ }^{\circ} \mathrm{C}$.

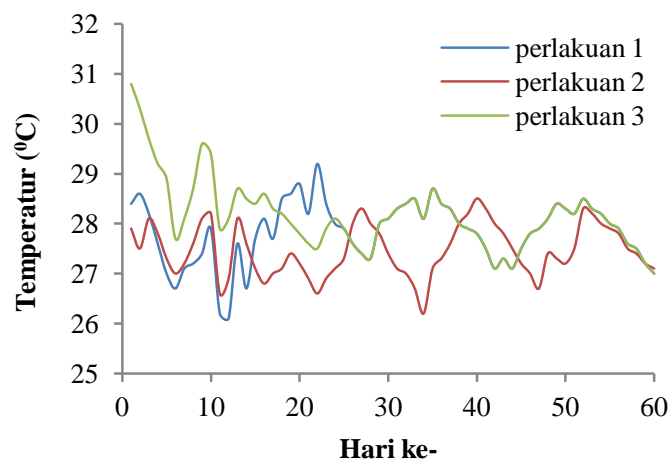

Gambar 1. Pengaruh Variasi Volume Slurry terhadap Suhu Kompos

Berdasarkan teori, dekomposisi bahan organik oleh mikroorganisme tergantung kadar air [6]. Penambahan slurry dapat meningkatkan kelembaban sekam padi yang relatif kering sehingga membantu proses pengomposan. Dengan terciptanya kondisi kelembaban yang sesuai untuk pengomposan, maka mikroorganisme dapat beraktivitas dengan baik dalam proses dekomposisi sehingga meningkatkan temperatur [8]. 


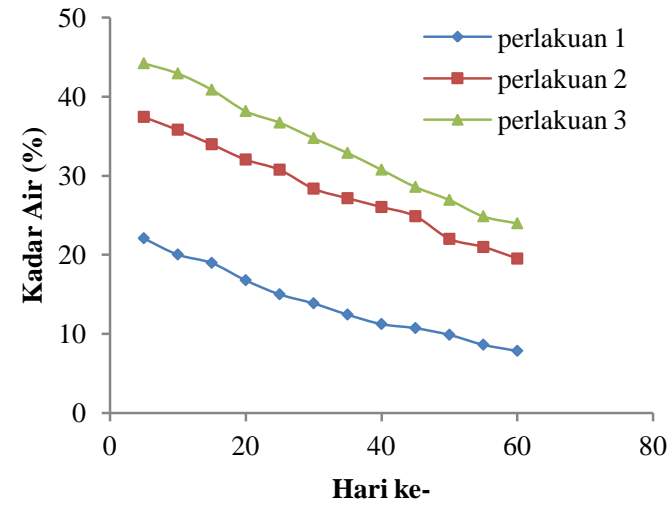

Gambar 2. Pengaruh Variasi Volume Slurry terhadap Kadar Air Kompos

Gambar 2 memperlihatkan pengaruh penambahan slurry pada berbagai volume di awal pengomposan terhadap kadar air. Berdasarkan gambar dapat dilihat bahwa nilai kadar air yang diperoleh mengalami penurunan. Pada akhir proses pengomposan juga dapat dilihat bahwa semakin besar volume slurry yang digunakan maka semakin besar pula kadar air yang diperoleh. Dimana dari gambar di peroleh nilai kadar air untuk tiap variasi kompos berkisar antara 7,86-23,99\%. Nilai kadar air tersebut sesuai dengan nilai kadar air dalam SNI 197030-2004 (Standar Nasional Indonesia) yaitu kurang dari $50 \%$ [3]. Kadar air terendah yaitu pada perlakuan 1 yaitu $7,86 \%$ dan tertinggi pada variasi perlakuan 3 yaitu sebesar 23,99\%.

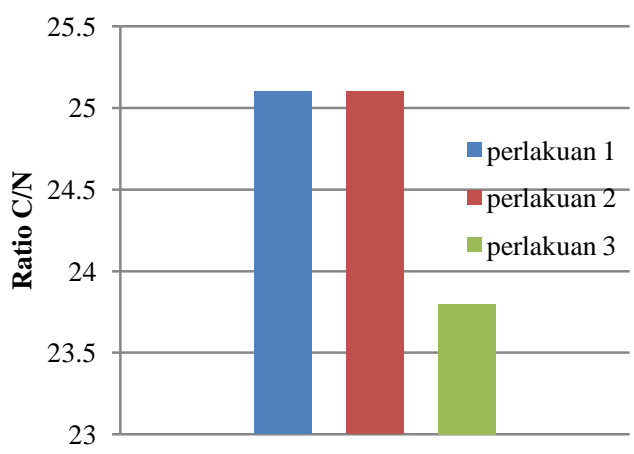

\section{Gambar 3. Pengaruh Variasi Volume Slurry} terhadap C/N Kompos

Gambar 3 memperlihatkan pengaruh penambahan slurry pada berbagai volume di awal pengomposan terhadap ratio $\mathrm{C} / \mathrm{N}$. Dari gambar dapat dilihat bahwa harga ratio $\mathrm{C} / \mathrm{N}$ untuk perlakuan 1 dan 2 lebih besar dari perlakuan 3. Rasio $\mathrm{C} / \mathrm{N}$ terendah yaitu terdapat pada perlakuan 3 yaitu sebesar 23,8 dan tertinggi pada perlakuan 1 dan 2 yang memiliki nilai ratio $\mathrm{C} / \mathrm{N}$ yang sama yaitu 25,1 .

Berdasarkan teori, penurunan nilai $\mathrm{C} / \mathrm{N}$ bahan akibat dari semakin meningkatnya aktivitas mikroorganisme yang melakukan proses perombakan bahan organik. Dengan demikian, penambahan slurry berpengaruh dalam menciptakan kondisi yang sesuai untuk kehidupan mikroorganisme.

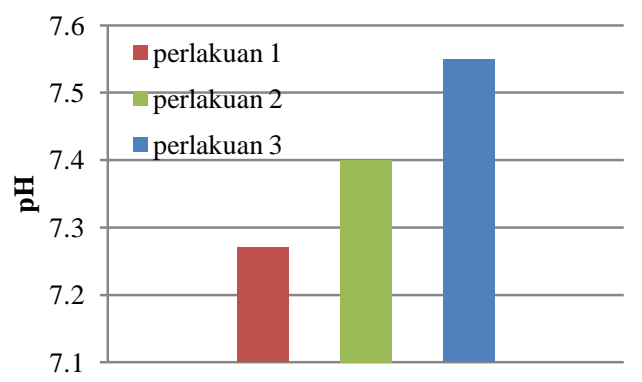

\section{Gambar 4. Pengaruh Variasi Volume Slurry terhadap pH Kompos}

Dari gambar dapat dilihat bahwa nilai $\mathrm{pH}$ mengalami peningkatan. Untuk perlakuan 1-3 berada di antara $\mathrm{pH}$ yang optimum untuk proses pengomposan yaitu berkisar antara 7,27-7,55. Dengan harga $\mathrm{pH}$ terendah sebesar 7,27 untuk perlakuan 1 dengan komposisi bahan $2,5 \mathrm{~kg}$ sekam padi, 1 liter slurry dan $1 \mathrm{~kg}$ kompos halus. Dan harga $\mathrm{pH}$ tertinggi sebesar 7,55 untuk perlakuan 3 dengan komposisi 2,5 kg sekam padi, 3 liter slurry dan $1 \mathrm{~kg}$ kompos halus.

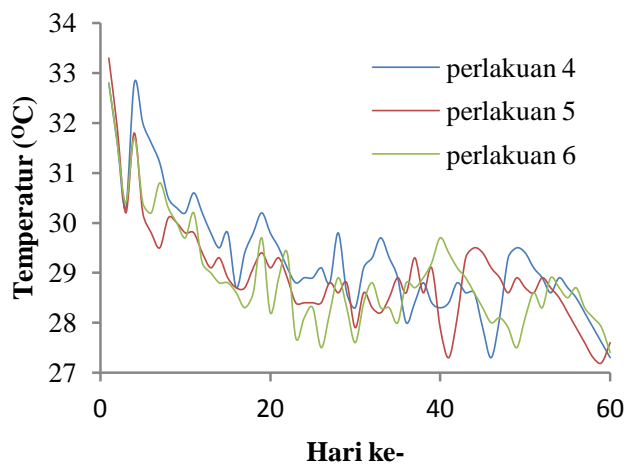

Gambar 5. Pengaruh Variasi Volume Slurry Pengomposan terhadap Suhu Kompos

Gambar 5 memperlihatkan pengaruh penambahan slurry pada berbagai volume terhadap suhu. Dari gambar dapat dilihat suhu maksimum yang dapat dicapai untuk perlakuan 4 dan 6 adalah 32,8 sedangkan pada perlakuan 5 adalah 33,3 . 
Dekomposisi bahan organik oleh mikroorganisme tergantung kadar air. Penambahan slurry ke tumpukan kompos akan meningkatkan kadar air sekam padi yang relatif kering. Dengan terciptanya kondisi kelembaban yang sesuai untuk pengomposan, maka mikroorganisme dapat beraktivitas dengan baik dalam proses dekomposisi sehingga meningkatkan temperatur.

Pada penelitian ini, volume slurry yang ditambahkan tidak menunjukkan perbedaan yang nyata pada temperatur. Walaupun demikian, dari pengamatan visual penambahan slurry sebanyak 2 liter / 3 hari menunjukkan hasil yang lebih baik terhadap proses pengomposan. Hal ini ditandai penguraian kompos pada perlakuan 6 lebih cepat dibandingkan perlakuan 4 dan perlakuan 5 .

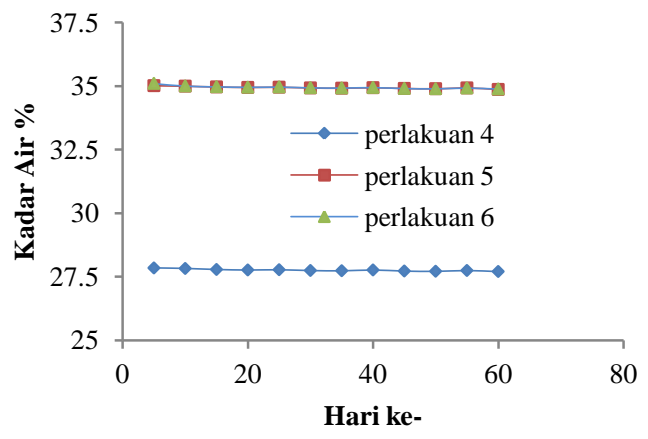

Gambar 6. Pengaruh Variasi Volume Slurry terhadap Kadar Air Kompos

Gambar 6 memperlihatkan pengaruh penambahan slurry pada berbagai volume terhadap kadar air. Pada gambar 6 dapat dilihat bahwa nilai kadar air yang diperoleh mengalami fluktuasi berdasarkan volume slurry yang digunakan, dimana dari gambar diatas dapat dilihat bahwa kadar air untuk tiap variasi kompos berkisar antara 27,7 - 35,1\%. Nilai kadar air tersebut sesuai dengan kadar air dalam SNI 197030-2004 (Standar Nasional Indonesia) yaitu kurang dari 50\%. Kadar air terendah terdapat pada perlakuan 4 sebesar $27,7 \%$ dan tertinggi pada variasi perlakuan 6 yaitu sebesar $35,1 \%$.

Timbunan bahan yang dikomposkan perlu dijaga kelembabannya karena bila kelebihan air akan mengakibatkan volume udara jadi berkurang. Semakin basah timbunan tersebut, maka harus semakin sering diaduk, untuk menjaga dan mencegah pembiakan bakteri anaerobic [9].

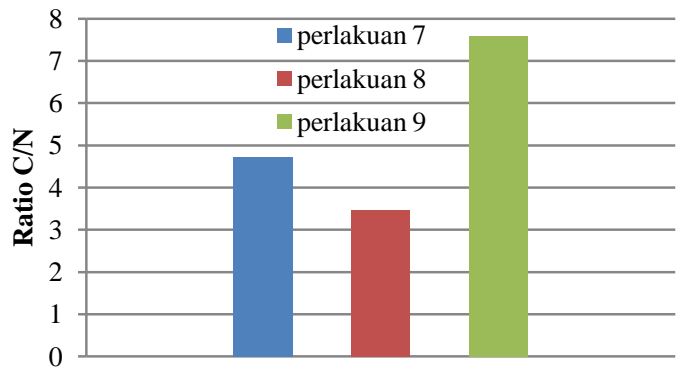

Gambar 7. Pengaruh Variasi Volume Slurry terhadap Ratio C/N

Gambar 7 memperlihatkan pengaruh penambahan slurry pada berbagai volume terhadap Ratio C/N. Dari gambar dapat dilihat bahwa nilai ratio $\mathrm{C} / \mathrm{N}$ tertinggi terdapat pada perlakuan 6 dengan nilai 7,58 dan terendah pada keranjang 5 yaitu 3,48. Nilai tersebut lebih kecil dari 10. Nilai $\mathrm{C} / \mathrm{N}$ tersebut tidak sesuai dengan rasio C/N dalam SNI 19-7030-2004 (Standar Nasional Indonesia) yaitu antara 10-20 [3].

Penurunan nilai $\mathrm{C} / \mathrm{N}$ bahan akibat dari semakin meningkatnya aktivitas mikroorganisme yang melakukan proses perombakan bahan organik. Timbunan yang bernitrogen terlalu sedikit (zat yang dibutuhkan mikroorganisme penghancur untuk tumbuh dan berbiak) tidak akan menghasilkan panas untuk membusukkan material dengan cepat. Tetapi kadar $\mathrm{C} / \mathrm{N}$ yang tinggi bisa menyebabkan timbunan itu membusuk pelan-pelan lewat kerja zat-zat organis suhu rendah (kebanyakan jamur) [9].

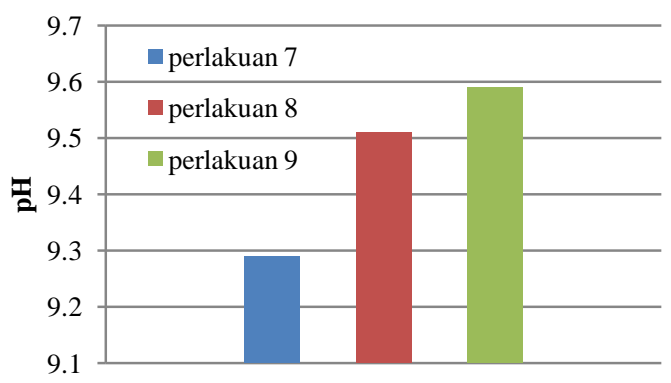

Gambar 9. Pengaruh Variasi Volume Slurry terhadap Ratio pH Kompos

Gambar 8 memperlihatkan pengaruh penambahan volume slurry selama proses pengomposan terhadap $\mathrm{pH}$. Pada gambar 4.13 dapat dilihat bahwa pada perlakuan 4, 5 dan 6 dilakukan penambahan slurry setiap 3 hari sekali dan dapat dilihat dimana terjadi peningkatan $\mathrm{pH}$ pengomposan. Pada keranjang 4 diperoleh $\mathrm{pH}$ sebesar 9,29, keranjang 5 diperoleh $\mathrm{pH}$ 9,51 dan keranjang 6 dengan $\mathrm{pH}$ 9,59 sehingga keadaan kompos berubah menjadi basa. 
Hal ini disebabkan asam - asam organik sederhana yang terbentuk pada dekomposisi awal tadi dikonversi menjadi methane dan $\mathrm{CO}_{2}$ oleh bakteri pembentuk metan.

Setelah mengalami kenaikan hingga titik tertinggi seluruh variasi tumpukan kompos menunjukkan perilaku yang hampir sama dan sampai akhir proses pengomposan nilai $\mathrm{pH}$ masih berfluktuatif tetapi masih dalam kisaran yang dapat diterima yaitu antara $5-12$.

\section{Kesimpulan}

Dari hasil penelitian dapat disimpulkan bahwa kondisi kompos yang hampir memenuhi kualitas kompos berdasarkan SNI 19-7030-2004 yaitu terdapat pada perlakuan 6, dimana suhu yang diperoleh yaitu $32,8{ }^{\circ} \mathrm{C}$, kadar air $35,1 \%$, ratio $\mathrm{C} / \mathrm{N} 7,58$ dan $\mathrm{pH} 9,59$. Berdasarkan hasil di atas dapat disimpulkan bahwa slurry dari fermentor biogas dari sekam padi dapat mempercepat kematangan kompos sehingga kompos lebih mudah terurai atau terdekomposisi.

\section{Daftar Pustaka}

[1] Ario Indarto, Penambahan Slurry Berpengaruh terhadap Pertumbuhan Kompos, Penerbit UI Press, Jakarta, 2005.

[2] Badan Penelitian dan Pengembangan Pertanian, Sekam Padi sebagai Sumber Energi Alternatif dalam Rumah Tangga Petani, Penerbit LPP, Yogyakarta, 2008.

[3] Badan Standarisasi Nasional (BSN), Spesifikasi Kompos dari Sampah Organik.

[4] Crawford, J, H, Composting of Agricultural Waste in Biotechnology Applications and Research, CRC Press London, 1994.

[5] Fitrah Mulyana, Perbedaan Kualitas Sampah Organik Menggunakan Sekam Padi (Oryza Sativa) Antara Penambahan Orgadec dengan EM4, Jurnal Makara Sains Vol 14 No.1, Jakarta, 2009.

[6] Golueke, C, G, Biological Processing, Composting and Hydrolisis, CRC Press London, London, 1997.

[7] Ismail, M. S. dan Waliuddin, A. M. Effect of Rice Husk Ash on High Strength Concrete. Construction and Building Materials. 10 (1): 521- 526,1996.

[8] Isroi, Kompos, Balai Penelitian Bioteknologi Perkebunan Indonesia, BPPT, Bogor, 2008.

[9] Murbandono, H.S. Membuat Kompos, Penebar Swadaya, Jakarta, 1997.
[10] Santoso, H, B, Kompos, Penerbit Kanisius, Jogjakarta, 1998.

[11] Sikka dan Satyawati, Biogas Slurry, PW NU Sumbar Latih Petani Buat Pupuk Organik, Jakarta, 1991.

[12] Wahyono, Mengolah sampah Menjadi Kompos, Pusat pengkajian dan Penerapan Teknologi Lingkungan BPPT, Jakarta, 2003.

[13] Widodo, Pemanfaatan Limbah Industri Organik Pertanian untuk Energi Biogas, UI Press, Jakarta, 2007. 